\title{
Article \\ Commonalities and Differences of Cluster Policy of Asian Countries; Discussion on Cluster Open Innovation
}

\author{
Arkadiusz Michał Kowalski *(D) and Marta Mackiewicz
}

check for updates

Citation: Kowalski, A.M.;

Mackiewicz, M. Commonalities and Differences of Cluster Policy of Asian Countries; Discussion on Cluster Open Innovation. J. Open Innov. Technol. Mark. Complex. 2021, 7, 21. https://doi.org/10.3390/joitmc7010021

Received: 26 November 2020

Accepted: 5 January 2021

Published: 8 January 2021

Publisher's Note: MDPI stays neutral with regard to jurisdictional clai$\mathrm{ms}$ in published maps and institutional affiliations.

Copyright: $(2021$ by the authors. Licensee MDPI, Basel, Switzerland. This article is an open access article distributed under the terms and conditions of the Creative Commons Attribution (CC BY) license (https:// creativecommons.org/licenses/by/ $4.0 /)$.
Department of East Asian Economic Studies, Collegium of World Economy, SGH Warsaw School of Economics, 02-521 Warsaw, Poland; marta.mackiewicz@sgh.waw.pl

* Correspondence: arkadiusz.kowalski@sgh.waw.pl

\begin{abstract}
The article aims at investigating the commonalities and differences between cluster policies in selected East Asian and Southeast Asian countries: Thailand, Singapore, South Korea, and China, to outline the Asian model of a cluster policy. Clusters play a significant role in the economic development of these countries, and some practical experiences from Asia may be used to shape the cluster policy in the recovery process after the COVID-19 pandemic. The conducted research contributes to a better understanding of the cluster formation process, cluster development, and policy aims in the analyzed countries. In Singapore and South Korea, which are among the most innovative countries in the global economy, cluster policy is to a great extent part of innovation policy, focusing on facilitating the networking and cooperation between science and business, the flow of knowledge, transfer of technology, and developing innovative technologies of key economic importance. In China and Thailand, which are developing countries, there is a much stronger role of foreign direct investments, which take the central place in the cluster structure. However, one common characteristic of cluster development patterns in all the analyzed countries is a top-down approach, where clusters are emerging and developing mostly as a result of governmental decisions and public programs.
\end{abstract}

Keywords: clusters; cluster policy; Asia

\section{Introduction}

In the last three decades, a dynamic increase in the importance and popularity of clusters has been noticeable, both as a business model used to organize economic activity and as an instrument within a state's economic policy. Clusters contribute to sustainable development [1], and there is growing research interest explaining the relationships between these two concepts $[2,3]$. Clusters are recognized as an important factor influencing sustainable development because they are able to influence the strategic goals of business and scientific units associated in clusters by local governments, build social and relational capital based on trust, and stimulate innovation, including eco-innovation and technology transfer $[4,5]$. The positive examples of creating competitive clusters in many regions of the world encourage public authorities to formulate strategies and economic policy instruments aimed at developing cluster structures, seen as a way to overcome structural difficulties and increase innovation and competitiveness of the economy. While most research examines various clusters and related government actions in developed market economies, generally in the USA and the European Union, far fewer studies have zeroed-in on countries in East and Southeast Asia. Such examinations, along with the expanding prevalence of clusters as an economic policy tool, have observed critical deviations from Porter's original approach and different trajectories of clusters and cluster policy advancement worldwide.

The cluster-based economic development policy, formulated the Organisation for Economic Co-operation and Development (OECD) Forum, is understood as a set of policy measures used by public authorities to increase the level of competitiveness of countries 
and regions by stimulating the development of existing or creating new cluster systems [6]. In practice, there are different models of public intervention adopted by governments, with two dominant cluster policy models or a mix [7]:

(1) The bottom-up approach, with clusters driven mostly by market forces, with the key role played by enterprises,

(2) The top-down approach, where the creation of clusters is a result of government actions.

Supporting clusters depends on the view that organizations and specific industries are connected with various direct and indirect relationships [8]. Adding to the building of "collective efficiency" cluster policy in the region is perceived as increased profits identified with external benefits, in turn, achieved by those economic entities that are broadly clustered [9]. Activities most commonly taken forward subject to cluster policy is the provision of support either financially or non-financially to existing clusters and expounding the marketability of clusters as a business model [10].

The research intended to evaluate and assess the cluster policies of selected Asian countries. The available literature endeavors to describe the Asian model of cluster policy, with many observable differences in comparison to more developed market economies, like the USA and the EU [11]. For example, the Asian policy model described by Kuchiki [12] has established sequential actions in the flowchart approach, and the importance of the ordering of policy measures is emphasized. However, the question if there is a universal Asian model of cluster policy still needs to be explored, which is a research question raised in this article.

The analysis was carried out for four countries: Thailand, Singapore, China, and South Korea, which are very diverse in many respects - economic development level, nature of the economy, size of the country, etc. Therefore, a differentiated approach to a cluster policy with hardly any commonalities could be expected. The hypothesis based on this supposition states that cluster policy is an important element of economic policy in all the analyzed countries, but there is no single Asian model of cluster policy that could be described by common features or sequence of policy actions. The focus was on the strategic directions and instruments of cluster policy in the analyzed countries. This focus served to formulate recommendations for cluster policy in the recovery process after the COVID-19 pandemic.

\section{Materials and Methods}

This article was based on international comparative analyses of different models of cluster development and policy in selected Asian economies. Qualitative analysis was based on a critical review of existing literature and publicly available information, documents, and strategies, as well as government regulations, studies, and cluster-funding programs, which help in the implementation of cluster policies. The unified methodology of the research was applied in each of the countries studied, including the approach to cluster policy (e.g., top-down versus bottom-up), cluster internationalization, level of a cluster policy, and its main features.

As part of the study, an analysis of the cluster policies implemented in selected countries was carried out, taking into account the division of tasks in the field of cluster policy implementation between central and regional and local administration as well as the classification of cluster-based economic policy levels proposed by Enright [13]. An analysis of cluster support systems was carried out, taking into account the identification and analysis of differences in the type and scope of intervention depending on the stage of cluster development. Cluster support instruments in the analyzed countries were identified and analyzed. 


\section{Results}

3.1. Characteristics of Clusters in Thailand, Singapore, South Korea, and China

\subsubsection{Thailand}

In 2002, the Thai national planning agency, the National Council for Economic and Social Development (NESDB), coordinated the implementation of a cluster mapping project. This project was aimed at increasing the competitiveness of Thai business, examining and analyzing the current situation of clusters across the country, as well as reviewing the conceptual framework, evaluation criteria for cluster development, and existing models of cluster development implemented both locally and internationally. Clusters were evaluated and categorized to develop appropriate, practical policy recommendations and development approaches. As a result of the study, 60 clusters were identified, which were divided according to levels of development and potential into the following four groups [14]:

(1) Commencement and arrangement clusters, of thirty-two (32) clusters of moderate numbers of enterprises limited to the local market and with a commonality of similar products and services,

(2) Seeking direction clusters, of ten (10) clusters, which are nominally connected and tend to experience issues accessing markets because of lack of marketing and product management know-how,

(3) Developing clusters, of four (4) clusters, which are clusters with an obvious endeavor to improve and create strategies for growth with strong internal bonds,

(4) High potential clusters, of fourteen (14) clusters, which are clusters with advancement and innovation at a significant level.

Identification of the above types of clusters formed a basis for preparing the strategy of provincial cluster development policy, with the plan to set up 19 clusters in four regions of Thailand as follows [15]:

- Three clusters in the North (16 provinces) composed of IT cities and software parks based on foreign direct investment from the USA, Japan, and India.

- Five clusters in the Northeast (19 provinces) composed of OTOP (One Tambon One Product) movement-related R\&D and supporting industries developed by investments from the USA and Japan.

- Six clusters in the Central and the East with a concentration on biotechnology, agrorelated R\&D, automobiles, electronics, tourism, and distribution-related industries based on investments from Japan, South Korea, the USA, and the European Union.

- Five clusters in the South (14 provinces) specializing in tourism, distribution, rubber, Islamic halal food considering the connections with Malaysia and Singapore.

In the 2015 plan, Super Clusters were established in six sectors using advanced technology and future industries:

(1) Automotive and Parts Cluster;

(2) Electrical Appliances, Electronics and Telecommunication Equipment Cluster;

(3) Eco-friendly Petrochemicals and Chemicals;

(4) Digital-based Cluster;

(5) Food Innopolis;

(6) Medical Hub.

Analysis conducted by [11] showed that $2 / 3$ of the clusters selected in the first round of the SuperCluster program represented strong concentrations of specific industries in designated regions. It may be interpreted that these structures fulfill one of the key theoretical assumptions of Porter's model of clusters, i.e., geographical concentration of economic activity in a particular sector [16]. However, some clusters do not represent regional specialization, which shows that a top-down policy process may lead to the selection of some structures, which, although formally called clusters, do not necessarily represent local strengths, and existing assets. 


\subsubsection{Singapore}

In Singapore, there is a top-down approach to the creation of clusters, which means that clusters are built and developed on the initiative of the public sector. The government decides to create clusters based on simple criteria of dividing industries and sectors into:

(1) The manufacturing industry, where clusters have been initiated in five industries, which are energy and chemical production, precision engineering, marine, aerospace, and electronics. All these industries create products that can then be used in other industries;

(2) Construction and real estate;

(3) Trade and connectivity, where five industries are separated for the movement of people and products: logistics, air transport, maritime transport, land transport, and wholesale trade;

(4) Essential domestic services: healthcare and education, affecting the quality of life of a highly developed society, such as Singapore;

(5) Modern services, consisting of three industries: professional services, information and communication technologies (ICT), and media and financial services. All these services are used worldwide and create value for businesses;

(6) Lifestyle, food services, and hotels, which contribute to raising the standard of living and influence the development of tourism.

\subsubsection{Republic of Korea}

The foundations and provision of a physical infrastructure in The Republic of Korea to be utilized by small and medium size enterprises (SMEs), universities, research centers, business environment institutions, and local government bodies cooperating in networks have been developed by way of industrial complexes, linked to industrial estates and large science and technology parks.

A key role at the start of the cluster process was played by the central government, in time transferring to an industry-driven process with a significant role assigned to regional authorities. Therefore, cluster policies have depended on a joint top-down and bottom-up approach. To achieve cluster policy objectives of more territorially balanced development, new science and technology complexes were initiated by the government [17], while the technology parks and industrial complexes were transformed into innovation clusters. In Korea, the central government and regional authorities supported the evolution of production clusters to R\&D clusters and subsequently into innovation clusters.

\subsubsection{China}

In China, clusters contribute significantly to economic growth, being the engine of export-led economic growth. Clusters are formulated mainly in the labor-intensive manufacturing sectors. This means that they operate at the lower end of the global value chain. However, at the opposite end, higher up the supply chain are clusters that emerged in special economic zones (SEZ) in Beijing, Shanghai, and Shenzhen. These SEZ connections can be compared to the industrial complexes providing infrastructure in Korea. One of the factors contributing to the success of Chinese clusters is related to the fact that companies operate in various business segments, including related services. Therefore, they can form efficient and effective production networks [18].

Clusters are located in different regions, namely the Pearl River Delta, Yangtze River Delta, and Bohai Rim (Beijing-Tianjin-Liaoning), but the distribution is uneven-the largest number of clusters is located on the eastern coast. Some industrial clusters developed as centrally driven initiatives, but the majority emerged as bottom-up initiatives along with the coastal provinces as a result of a manufacturing specialization. For both types of clusters, the central government played an important role as a provider of technical infrastructure, technology and innovation support, finance, and human capital [19].

Clusters are active mainly in the manufacturing of low value-added goods, e.g., agriculture, but the number of high-tech industry clusters is increasing. The spontaneously 
developed clusters operate mostly in low technology and labor-intensive sectors, while the government-driven initiatives in high-tech industries [20].

Many clusters located on the eastern coast are foreign direct investment (FDI)-driven. For example, foreign companies, such as Acer, Compaq, IBM, and other computer producing companies, established plants in Dongguan and Huizhou [18].

\subsection{Model of Public Support}

\subsubsection{Thailand}

The history of cluster policy in Thailand may be traced back to 2002 when the provincial cluster development policy was launched in the Ninth National Economic and Social Development Plan for 2002-2006, whose point was to create clusters in each province as independent settlements. Consequently, provincial competition with Bangkok had been enabled by the use of cluster policy as a significant tool. The Tenth National Economic and Social Development Plan for 2007-2011 highlighted the importance of provincial cluster development policy; however, it did not occasion any serious policy actions at that time. The need to support the business innovation through cluster development by strengthening links and cooperation throughout the supply chain was featured at The Eleventh National Economic and Social Development Plan for 2012-2016. Governments globally are incentivized to create and implement clustering processes by the success of their regional economies that have prospered with cluster structures.

Thailand's strategy introduced in September 2015 was a turning point in the cluster policy, aiming to develop two types of clusters: SuperClusters and other targeted clusters. SuperClusters are of particular importance for the economy, and the motivation for their development is to increase national investment potentials, production, and international competitiveness, especially in terms of trade competitiveness. The characteristic feature of the SuperCluster policy in Thailand is the fact that assisted companies appear to act in isolation, and no coordinating structures in the form of cluster initiatives are required. This brings this policy closer to the special economic zones (SEZ) idea rather than to the traditionally understood cluster policy concept [11].

\subsubsection{Singapore}

In Singapore, there is a top-down approach to the creation of clusters, which means that clusters are built and developed by public sector initiatives. The shaping and implementation of cluster policy in Singapore take place at the central level. Due to the small size of this city-state, there is no regional or local level. The key entity responsible for cluster policy-making in Singapore is the Ministry of Trade and Industry and for its implementation, the National Research Foundation, which coordinates the implementation of cluster development strategies. Excellent cooperation of consulting agencies creates an effective environment that facilitates the development and helps to avoid mistakes that are difficult to compensate for. However, it is important to note the top-down nature of this policy, in which the key role in the process of cluster development is played by the public administration. Simultaneously, cluster policy in Singapore serves the development of entire industries. A person, a company, or a group of companies does not receive direct subsidies; hence, no catalog of eligible costs or list of supported activities was formulated. The basis of this intervention is the belief that the development of a given industry will have a positive impact on all companies operating in it, which will benefit from the spillovers.

Cluster policy in Singapore plays an important role in facilitating the flow of knowledge, transfer of ideas, and support of new ways of developing innovative technologies of key economic importance. The instruments implemented have an impact on the creation of new industries, jobs, patents, and the commercialization of research. In particular, the impact of the I\&E Fund, which is characterized by effectiveness in stimulating cooperation between science and business, labor market expansion, and complementing value chains in the industry, should be highly valued. The strengths of cluster policy in Singapore are: 
- Selection and concentration of support on the most important clusters from the perspective of innovation and competitiveness of the economy,

- Linking cluster policy with innovation policy and supporting clusters in the context of R\&D activities, technology transfer, and cooperation between science and business,

- Involvement of various types of industrial entities, such as trade associations and the chamber of commerce, in shaping cluster policy.

\subsubsection{Republic of Korea}

According to the OECD, South Korea shows an intermediate degree of delegation of powers to the regional and local levels. Although the main initiative in the field of cluster policy comes from the central authorities, local governments can contribute to the implementation of changes, taking into account the specificity of the area [18]. The influence of regional institutions is present at every stage of implementation-they manage the planning process and assess infrastructure development and provide support tailored to regional conditions.

Cluster policy in South Korea gained popularity in response to the adoption of the Balanced National Development Plan 2004-2008. This plan was based on three principles: (1) decentralization of the state and promotion of alternative locations to Seoul; (2) supporting regional innovation systems to help regions become more self-sufficient; (3) building foundations for the development of metropolitan areas.

The first phase of cluster policy in South Korea, the formation phase, took place in the years 2004-2009. The Korean government then sought to build the foundations of clusters based on foreign experiences, e.g., French or Japanese. In the first phase, the government created seven clusters: Changwon (machines), Gumi (electronics), Ulsan (automotive), Banwol, Shiwha (textile), Gwangju (mining), and Wonju (medical devices).

The second phase of cluster policy—the growth phase-took place in 2010-2012. At that time, there was a quantitative expansion of the supported clusters, and the number of clusters increased to 193. Along with the increase in the number of clusters, the government strengthened the network of cooperation between clusters by organizing technology seminars and information sessions. The interregional cooperation, as well as integration in global value chains, had been added to policy objectives.

The third phase of cluster policy development—-the maturity phase—started in 2013. The support was focused on specialized clusters, mainly in high technology industries. The policy was also strongly geared towards strengthening linkages between clusters. The government's policy in the maturity phase was aimed at the sustainable development of clusters and, therefore, the investments in agricultural and environmentally friendly industrial clusters.

\subsubsection{China}

China's public cluster policy is developed by both the central and provincial governments. The National Development and Reform Commissions promoted guidelines for development processes regarding industrial clusters and, as such, were supported by both central and local government; however, most of the industrial clusters in China arose spontaneously. China's cluster policy is focused on strengthening specialization, backing innovation, and competitiveness by uniting universities, companies, and R\&D institutions.

The creation of clusters started in the late 1970s along with the introduction of the concept of 'one village, one product', the implementation of which led to a specialization in production. Thus, cities specializing in specific productions were granted funding for investment in innovation centers [21]. Besides, they have a sectoral or technological focus in manufacturing or services. Albeit, initially, the special economic zones were established to attract foreign direct investment.

To achieve this objective, 19 supercity clusters were selected. They represent different sectors, e.g., financial services, advanced manufacturing, ICT, leisure and tourism, logistics, heavy industry. 


\subsection{Instruments of Cluster Policies}

\subsubsection{Thailand}

Until 2015, when the SuperCluster strategy in Thailand was formulated, there were no specific instruments to influence the development of clusters but only some strategic direction of development of, e.g., provincial clusters.

A 269 million USD grant has also been approved by the Thai government, which includes matching grants for investors in the high value-added activities in the SuperCluster, like R\&D and training. Since 2015, the instruments for Thai Super Clusters include:

- A $50 \%$ reduction of corporation tax on net profits derived from the promoted activity for 5 years;

- Import duty relief for machinery, raw materials, and components imported for reexport;

- Specialists and experts to be considered for Permanent Residence status if required;

- Land ownership will be permissible to foreigners to facilitate business activities;

- Corporation tax relief for 8 years.

To qualify for those instruments, companies submit applications, which are then considered by The Thailand Board of Investment (BOI) based on the following approval criteria:

- The activity should be classified under eligible BOI categories,

- The activity should be located in the designated provinces for each relevant cluster,

- Applicants should cooperate with academic institutions, research institutions, or centers of excellence in the designated areas.

What is characteristic of the SuperCluster policy in Thailand is that financial support is granted to individual companies. This approach differs from the instruments used in Europe and the United States, where public support is usually directed through cluster organizations to encourage different types of collaborative actions between cluster members or to benefit the whole cluster. For the Super Clusters in Thailand, the only approval criteria for receiving public support connected with cooperation at the local level is to cooperate with universities, research institutions, or centers of excellence in specific locations. Apart from that, assisted companies appear to act in isolation, and coordinating structures in the form of cluster initiatives are not required. This is another characteristic that brings the Super Clusters in Thailand closer to the SEZ idea rather than to the cluster policy concept.

\subsubsection{Singapore}

One of the key cluster policy instruments in Singapore is the Innovation and Enterprise Cluster Fund (I\&E), launched under the Research, Innovation, and Enterprise 2020 (RIE2020). This fund aims to support projects responding to the specific needs of clusters operating in different areas of the economy, in particular, supporting research, development, and innovation activities. Since the paths of commercialization vary from the field of science and often it is not possible to implement them under general programs, clusters from different areas can benefit from the I\&E fund, which is a flexible program with a wide range of possible applications, determined according to the identified development needs of the cluster. In particular, this instrument is used to strengthen partnerships between businesses, universities, research institutes, and government to quickly bring ideas to market, increase productivity, create jobs, and develop individual industries. Cluster development plans also include support for projects to create common infrastructure, building the technological potential of cluster participants, and filling gaps in value chains.

In Singapore, the selection of clusters supported by cluster policy is based on a political decision of the government, so it is a top-down approach. The largest intervention undertaken under the I\&E Cluster Fund is the creation of Diagnostics Development Hub (DxD Hub), which is a medical cluster specializing in developing diagnostic solutions for Asian diseases. Utilizing the strengths of Singapore and leading clinicians and medical consortia in areas, such as oncology, ophthalmology, infectious, and cardiovascular diseases, 
as well as easy access to samples from Asian patients, DxD Hub develops diagnostic solutions tailored to diseases occurring mainly on the Asian continent.

\subsubsection{Republic of Korea}

The Industrial Complex Cluster Program, implemented in 2005, being the Korean government's longstanding cluster policy tool, was implemented in three distinct stages, with the focus of transforming the existing industrial complexes into innovation clusters while furthering competitiveness. The first stage, (2005-2009), was devoted to promoting Korean-style clusters with the designation of model innovative clusters, comprising seven national industrial complexes and one national science and technology special zone. The combined goals of these model clusters were to create regional economic growth by strategic development of industry and expand competitiveness to generate regional economic growth while creating a local innovation system to enhance cooperation with academia. The second stage (2009-2012) focused on the integration of the achievements of the first stage and extension of the model to all clusters. The third stage (2013-2016) consolidated the other two stages, committed to creating and executing R\&D programs and building self-sustainable clusters based on the accepted set up of industry, academic, R\&D, and government institutions, all of which were in collaboration. This heavily R\&D-based approach with support in various areas, including but not limited to management, skills, and marketing, encourages SME's involvement in innovation ecosystems. This project was launched to target agglomerated companies as opposed to creating new ones with the internationalization of clusters as an important objective.

Instruments at the regional level include regional cultural industry cluster building, support for regional culture clusters in six regions, regionally specialized IT clusters, and running specialized IT institutes in three regions to strengthen regional IT R\&D capacity.

\subsubsection{China}

In China, a cluster development program known as TORCH was implemented in 1998 by the central government. It is focused on the development of strategic emerging industries and high-tech industries, promoting the commercialization, industrialization, and internationalization of high-tech products manufactured in China. The TORCH program consists of two main parts: one devoted to industry and local projects, and the second to projects meeting the strategic needs of the country. The objective of the local part is to create high-tech zones, where universities, science parks, and technology transfer centers are located. Therefore, demonstration projects in emerging industries that rely on technology transfer are implemented there. The assumption is that the production will be exported. The second part supports the development of clusters in services like R\&D design, technology transfer, talent training, etc. [21].

\section{Discussion}

\subsection{Discussion on Commonalities and Differences of Cluster Policy in Analyzed Countries}

The analysis conducted in this study shows that Thailand's SuperCluster strategy diverges from the traditional, bottom-up approach to the role of the government in supporting clustering processes. The list of instruments used in support of Super Clusters is very similar to fiscal and non-fiscal incentives usually implemented in SEZs but, at the same time, far away from classical cluster policy tools indicated by M.E. Porter. The SuperCluster policy in Thailand is rather a variation of SEZs policy than a traditional approach to a government role in supporting clusters, taking into account both aims and instruments of this strategy. Usually, one of the key objectives of SEZs is to attract FDI, and this is also the main ambition of SuperCluster policy in Thailand. This shows the differences in clustering processes between developed and middle-income countries. In Europe or the USA, there is a much stronger role played by local enterprises, and clusters are built more on local assets, strengths, and existing social capital. In developing countries, for example, in Southeast 
Asia, it is more about attracting FDI with all related benefits, like financial capital inflow, job creation, increasing the level of domestic competition, technology transfer, etc.

An important part of Singapore's success story as an economic powerhouse and a city of innovation is the skillful implementation of good knowledge management and related strategies by policymakers and business leaders to create sustainable knowledge clusters with dynamic technology centers. The programs implemented by the Singaporean government as part of its cluster policy have been instrumental in realizing the vision of policymakers to achieve this:

(1) The systematic creation of knowledge centers, competence centers, and centers of excellence,

(2) Developing knowledge clusters as centers of knowledge and innovation,

(3) To transfer knowledge about clusters to all stakeholders in civil society, government, and business,

(4) Including clusters from Singapore in global networks of manufacturers,

(5) Using local knowledge to build comparative advantage in niche market areas.

South Korea has developed a complex cluster policy based on cooperation between the central, regional, and local levels. The development of clusters has contributed to this country's high position in innovation rankings. The success of the Gumi Industrial Park cluster has shown that the Korean government, by initiating activities in this area, has significantly contributed to the current domination of Korean companies in the electronics industry. Initially, clusters were used to attract FDI, which allowed for technology transfer and its dissemination among cluster participants. After moving to a higher level of development, Korean enterprises gradually began to conduct independent research, which opened up opportunities for independent development and gaining a leading position in the global market.

In China, industrial clusters can be considered not only as a policy target but also as an important development tool [22]. Clusters improve the firms' competitiveness and contribute to the upgrading skills of the workforce, contributing to an endogenous development of the region where are located [23]. The recent research provides evidence that they enhance local economic growth substantially and help to reduce local urban-rural income inequality by increasing the income of local rural residents [24]. Chinese clusters differ from industrial clusters in other countries-they are characterized by a stronger role of public institutions and lower informal social capital. They have a stronger industry concentration than in the other parts of the world. The success of Chinese clusters is linked to (a) efficiency gains and lower entry barriers, (b) effective support of the local government, (c) knowledge, technology, and skill spillovers through inter-firm linkages, (d) entrepreneurial spirit and the social network, (e) innovation and technology support from research institutes and public institutions, and (f) support from industry associations and other intermediary organizations [20]. Cluster policy in China is also used to promote more balanced regional development by opening up the western region in the country. A special role in this process is played by Belt and Road Initiative (BRI), as its vision document makes the recommendation to develop inland regions, with a focus on the city clusters along the Yangtze River, especially in the neighborhood of Chengdu and Chongqing. Cities are extremely important in BRI, as highlighted by the concept of the Silk Road Cities Network, presenting the idea of the system of cities clustered along the New Silk Road clustered into a network complex [25].

The analyzed models of cluster policies in Asian countries (China, Singapore, South Korea, Thailand) show that the assumptions of cluster policy and the way of its planning and implementation differ from European patterns. In all these countries, cluster policy is implemented at the central level (strong regional cluster policy distinguishes only South Korea), as per the top-down approach (clusters are created on the initiative of the public sector), serving to solve socio-economic problems, but also to increase the industrialization of these countries, attracting foreign direct investment (especially in Thailand) and developing modern technologies (Table 1). Cluster policy is closely related to innovation policy and 
focuses on supporting the most innovative and competitive sectors of the economy. As in European countries, support is given to activities related to the development of innovation and R\&D activities but also technology transfer and attracting direct foreign investments. A characteristic feature of Asian countries is the creation of cluster development strategies in key sectors of the economy (often high-tech) and the use of these clusters as an instrument for building a long-term competitive advantage in the international arena, as well as the continuity of support provided. In Asian countries, the analysis shows development paths from industrial to innovative clusters, while, in Europe, there is a shift towards new fields of technology specialization.

Table 1. Asian model of a cluster policy.

\begin{tabular}{ccccccc}
\hline Country & $\begin{array}{c}\text { Top-Down } \\
\text { Formation }\end{array}$ & $\begin{array}{c}\text { Bottom-Up } \\
\text { Formation }\end{array}$ & FDI-Driven & $\begin{array}{c}\text { Focused on } \\
\text { Innovation }\end{array}$ & $\begin{array}{c}\text { Focused on Regional } \\
\text { Development }\end{array}$ & $\begin{array}{c}\text { Focused on } \\
\text { Internationalization }\end{array}$ \\
\hline China & $\mathrm{x}$ & $\mathrm{x}$ & $\mathrm{x}$ & $\mathrm{x}$ & $\mathrm{x}$ & $\mathrm{x}$ \\
Korea & $\mathrm{x}$ & $\mathrm{x}$ & $\mathrm{x}$ & $\mathrm{x}$ & $\mathrm{x}$ & \\
Singapore & $\mathrm{x}$ & $\mathrm{x}$ & & $\mathrm{x}$ & $\mathrm{x}$ & $\mathrm{x}$ \\
Thailand & $\mathrm{x}$ & & & & \\
\hline
\end{tabular}

A good practice is a long-term cluster policy (China, Korea). A long-term policy allows for evolution towards higher specialization or specific objectives, such as internationalization.

Table 2 reflects the economic policy levels proposed by Enright and the classification of the analyzed countries according to the categories. The two lowest levels, i.e., non-existent role and catalytic role, in which public authorities limit themselves only to organizing meetings of cluster partners, do not apply in the analyzed countries.

Table 2. Levels of a cluster policy.

\begin{tabular}{cccc}
\hline Country & Supportive Role & Directive Role & Interventionist Role \\
\hline China & $\mathrm{x}$ & $\mathrm{x}$ & \\
Korea & & $\mathrm{x}$ & $\mathrm{x}$ \\
Singapore & & & \\
Thailand & & & \\
\hline
\end{tabular}

Table 3 provides information about the main characteristics of the cluster policy by country. The first category of support concerns the development of the policy-whether it is adjusted to the development of clusters and changes its form accordingly or whether the support is declining when clusters achieve maturity. The second type reflects the objectives of the support-whether it is focused on the operation of clusters or aimed at wider socio-economic results. 
Table 3. Main features of a cluster policy.

\begin{tabular}{|c|c|c|c|c|c|}
\hline \multirow{2}{*}{ Country } & \multirow{2}{*}{ Main Objective } & \multicolumn{2}{|c|}{ Type of Support } & \multicolumn{2}{|c|}{ Type of Support } \\
\hline & & Evolutionary & Regressive & Subjective & $\begin{array}{l}\text { Project- } \\
\text { Based }\end{array}$ \\
\hline China & $\begin{array}{l}\text { Development of high-tech industry, promoting } \\
\text { innovation, entrepreneurship, and } \\
\text { commercialization of R\&D results. }\end{array}$ & $\mathrm{x}$ & - & $x$ & $\mathrm{x}$ \\
\hline Korea & $\begin{array}{l}\text { Development of specialized clusters, primarily } \\
\text { in high-technology industries, strengthening } \\
\text { technological capabilities in clusters, including } \\
\text { the formation of human capital through } \\
\text { training and strengthening links } \\
\text { between clusters. }\end{array}$ & $\mathrm{x}$ & - & $x$ & $\mathrm{x}$ \\
\hline Singapore & $\begin{array}{l}\text { Top-down selection and concentration of } \\
\text { support on the most important clusters from } \\
\text { the perspective of innovation and } \\
\text { competitiveness of the economy. }\end{array}$ & $\mathrm{x}$ & - & - & $\mathrm{x}$ \\
\hline Thailand & $\begin{array}{c}\text { Tax incentives for foreign investors designated } \\
\text { by government Super Clusters. }\end{array}$ & $\mathrm{x}$ & - & $\mathrm{x}$ & - \\
\hline
\end{tabular}

\subsection{Cluster Open Innovation}

According to the open innovation paradigm, the sources of innovation may be found not only inside but also outside the company. With continuing technological development, it is not enough to rely solely on internal innovation resources. The existing fragmentation of knowledge in the modern world economy makes an effective innovation activity dependent mainly not on the internal resources of the organization but rather on an adequate mix of knowledge, skills, and activities of various actors who engage in different forms of cooperation. One of the best diagnosed methods of cooperation in the economy is clusters, in which relations between members create a system, enabling the companies with limited knowledge access to transfer it from local partners. Clusters may play the role of open innovation intermediaries, so supporting clusters increases openness to cooperation not only for member organizations but all actors in the regional innovation system [26]. There is a two-way relationship_open innovation of companies can determine the creativeness and complexity of cluster, whereas, at the same time, the openness and creativeness of the cluster determine the degree of open innovation of belonging members.

The adoption of open innovation strategies is important in restricted geographical contexts but with several limitations [27]. The absorption of external knowledge constitutes an input to firms' innovation activities in clusters. In the case of clusters, it is easier to use scientific knowledge, as universities and research institutes are members of cluster organizations. They provide knowledge that potentially can generate new technologies and possess state-of-the-art technical knowledge that is generated by applied research programs, often in cooperation with companies operating in clusters [28].

Adopting an open innovation strategy based on the absorption of scientific knowledge has several advantages. First, cooperation with other cluster members, including research organizations, facilitates the absorption of technology. Second, enterprises operating in a cluster are much less concerned about the risks of misappropriation of their knowledge. It is due to the fact that research organizations are not interested in competing directly in the market [29]. Other cluster members usually have complementary skills and benefit from cooperation. Therefore, in clusters, the situation differs from the usual market situation, when companies operating on the same market can use the absorbed knowledge in combination with technological, productive, and commercial resources to improve their competitive position to the detriment of their competitors [30]. 
Clusters create an excellent environment for the flow of knowledge because trust is built between cluster members based on common goals. It can be assumed that in Singapore and South Korea, where the cluster policy is focused on cooperation between science and business, the flow of knowledge, and transfer of technology, strategies based on open innovation will bring better results than in countries where networks and ability to absorb technology are weaker.

In China and Thailand, strategies for the absorption of external knowledge as an important input to innovation activities are associated with attracting foreign investments, which may allow the acquisition of knowledge, in particular, tacit knowledge. However, for these strategies to bring positive effects, an absorptive capacity must be in place-local companies and staff must have the ability to absorb innovation and implement new technologies. Hence, while an inflow of foreign direct investments is correlated with innovation performance in a host economy, the intensity of the spillover effects is determined by the absorptive capacity and the presence of innovation-related complementary assets in the host country [31,32].

Clusters provide a conducive environment to open innovation as the geographical proximity brings substantial improvements to the innovation process [33]. Hence, cooperation in the framework of clusters helps to look for sources of innovation development outside an organization, for example, by finding and combining ideas that are complementary to existing R\&D projects and the creation of cooperative relations with other units. The relations between clusters and the open innovation paradigm set out the directions for future research to turn to a consideration of the geography of openness, in which cooperation is based on proximity.

\section{Conclusions}

According to the results of the conducted research, there are considerable differences among cluster development models in the analyzed countries. In the Republic of Korea and in Singapore, which is among the most innovative countries in the world economy, cluster policy is to a great extent part of innovation policy, focusing on facilitating the cooperation between science and business, the flow of knowledge, transfer of technology, and developing innovative technologies of key economic importance. In China and Thailand, which are developing countries, there is a much stronger role of foreign direct investments, which take the central place in the cluster structure. Cluster policy in these counties is correlated with the special economic zones approach. There is also a weaker role of soft policy measures, for example, aiming at human and social capital formation in the regional economy. Moreover, clusters in these countries can be considered not only as a policy target but also as a wide development tool. Hence, there is no allowance in the results of the research to state that there is one universal Asian model of clusters and cluster policy. However, one common characteristic of cluster development patterns in all the analyzed Asian countries is a top-down approach, where clusters are emerging and developing mostly as a result of administrative decisions and public programs. The conclusion from the research is that there is no one universal model of cluster development and policy that should be followed by all countries, but different patterns for cluster development and cluster policies may be developed, taking into account different factors, like the level of social and economic development of a specific country, characteristics of an economic and political system, development needs, sectoral pattern, and technological advancement of the economy. Hence, we do not intend to recommend which model of cluster policy should be favored since there is no one-size-fits-all approach. This finding is consistent with those of many researchers, such as $[34,35]$. The importance of strengthening the comparative advantages of different economies and cluster-based cooperation is reinforced during the COVID-19 pandemic, which leads to the disintegration of many global value chains. Companies operating in a cluster are less exposed to the negative consequences of the COVID-19 pandemic. For example, Chinese firms in countries with a higher cluster index are more resilient, which can be explained by the proximity of customers and suppliers, as well as an 
informal business network [36]. Economic slowdown increases competition, but at the same time, making it necessary to strengthen policy measures, helping firms to achieve collective competitive advantage. One of the efficient approaches in the post-pandemic recovery is cluster policy, which during crisis play an important role in reducing information asymmetry, uncertainty, and risk, linking business and science and in increasing relational capital, trust, and location attractiveness for foreign direct investments.

The analysis leads to recommendations for cluster policy in the recovery process after the COVID-19 pandemic. According to the concept of cluster-based economic development policy, presented before, clusters can be used as tools for achieving policy objectives. Currently can be used to restore value chains. It requires an engagement of multiple actors at different stages of the value chain, including design, research, manufacturing, and supporting services. These strategies can be useful in Korea and Singapore. In developing Asian countries, like China and Thailand, clusters can be used to identify new technological trends, in particular, emerging at the cross-roads of different but connected sectors. Policymakers in all the analyzed countries should encourage clusters to work with community stakeholders in order to implement shared value projects that address the needs of post-COVID societies [37].

Author Contributions: Conceptualization, A.M.K. and M.M.; methodology, A.M.K. and M.M.; software, M.M.; validation, A.M.K. and M.M.; formal analysis, M.M.; investigation, A.M.K.; resources, M.M.; data curation, A.M.K.; writing—original draft preparation, A.M.K. and M.M.; writing—review and editing, A.M.K. and M.M.; visualization, M.M.; supervision, A.M.K.; project administration, M.M.; funding acquisition, M.M. All authors have read and agreed to the published version of the manuscript.

Funding: This publication is a result of research conducted by the Department of East Asian Economic Studies-a unit of the Collegium of the World Economy at the SGH Warsaw School of Economicsand financed with funds provided by the Polish Ministry of Science and Higher Education.

Data Availability Statement: Data available in a publicly accessible repository.

Conflicts of Interest: The authors declare no conflict of interest.

\section{References}

1. Derlukiewicz, N.; Mempel-Śnieżyk, A.; Mankowska, D.; Dyjakon, A.; Minta, S.; Pilawka, T. How do Clusters Foster Sustainable Development? An Analysis of EU Policies. Sustainability 2020, 12, 1297. [CrossRef]

2. Zaburanna, L.; Yarmolenko, Y.; Kozak, M.; Artyukh, T. Modelling of regional clusters considering sustainable development. Adv. Econ. Bus. Manag. Res. 2019, 99, 222-226.

3. Sonetti, G.; Lombardi, P.; Chelleri, L. True green, and sustainable university campuses? Toward a clusters approach. Sustainability 2016, 8, 83. [CrossRef]

4. Scheller, D.; Thörn, H. Governing 'Sustainable Urban Development' through self-build groups and co-housing: The cases of Hamburg and Gothenburg. Int. J. Urban Reg. Res. 2018, 42, 914-933. [CrossRef]

5. Raszkowski, A.; Bartniczak, B. Towards sustainable regional development: Economy, society, environment, good governance based on the example of Polish regions. Transform. Bus. Econ. 2018, 17, 225-245.

6. Organisation for Economic Co-operation and Development. Making Local Strategies Work—Building the Evidence Base; Organization for Economic Cooperation and Development: Paris, France, 2008.

7. Fromhold-Eisebith, M.; Eisebith, G. How to institutionalize innovative clusters? Comparing explicit top-down and implicit bottom-up approaches. Res. Policy 2005, 34, 1250-1268. [CrossRef]

8. Miller, C.R. The Tholian Web: The Political/Institutional Context of Regional Cluster-Based Economic Development. Ph.D. Thesis, Virginia Polytechnic Institute and State University, Blacksburg, Virginia, 2006; p. 22.

9. Krugman, P. Geography and Trade; MIT Press: Cambridge, MA, USA, 1991.

10. Ferreira, J.; Azevedo, S.; Raposo, M.L. Specialization of regional clusters and innovative behavior: A case study. Compet. Rev. Int. Bus. J. 2012, 22, 147-169. [CrossRef]

11. Kowalski, A.M. Towards an Asian Model of Clusters and Cluster Policy: The Super Cluster Strategy. J. Compet. 2020, 12, 74-90.

12. Kuchiki, A.; Tsuji, M. (Eds.) The Flowchart Approach to Industrial Cluster Policy; Palgrave Macmillan: Basingstoke, UK, 2008.

13. Enright, M.J. Regional clusters: What we know and what we should know. In Innovation Clusters and Interregional Competition; Brocker, J., Dohse, D., Soltwedel, R., Eds.; Springer: Kiel, Germany, 2003; pp. 99-129.

14. Wedel, P. Industrial Clusters for Improved Competitiveness in Thailand. Research Gate. 2003. Available online: https://www. researchgate.net/publication/247158112_Industrial_clusters_in_Thailand (accessed on 15 November 2020). 
15. Tsuneishi, T. The Regional Development Policy of Thailand and Its Economic Cooperation with Neighbouring Countries. IDE Discuss. Pap. 2005, 32. Available online: http://hdl.handle.net/2344/174 (accessed on 15 November 2020).

16. Kowalski, A.M.; Marcinkowski, A. Clusters versus cluster initiatives, with focus on ICT sector in Poland. Eur. Plan. Stud. 2014, 22, 20-45. [CrossRef]

17. The International Bank for Reconstruction and Development/The World Bank. Building Engines for Growth and Competitiveness in China: Experience with Special Economic Zones and Industrial Clusters; Zeng, D.Z., Ed.; The World Bank: Washington, DC, USA, 2010.

18. OECD. Industrial Policy and Territorial Development Lessons from Korea. Available online: https://www.oecd.org/korea/5056 0264.pdf (accessed on 30 October 2020).

19. Jankowiak, A.H. Cluster-Based Development: A Chinese Cluster Policy. 2017. Available online: http://cejsh.icm.edu.pl/cejsh/ element/bwmeta1.element.desklight-6956ec48-13ac-473d-a88e-ec00997a6e79 (accessed on 30 October 2020).

20. Zeng, D.Z. How Do Special Economic Zones and Industrial Clusters Drive China's Rapid Development? In Policy Research Working Paper 5583; The World Bank: Washington, DC, USA, 2011.

21. European Commission Directorate-General for Internal Market, Industry, Entrepreneurship and SMEs. European Observatory for Clusters and Industrial Change, Cluster Programmes in Europe and Beyond; Publications Office of the European Union: Luxembourg, 2019.

22. Frattini, F.; Prodi, G. Industrial clusters in China: Policy tools for further and more balanced development. Eur. Rev. Ind. Econ. Policy 2013, 5, 3-11.

23. Wang, J. Industrial Clustering in China: The Case of the Wenzhou Footwear Sector. In Building Engines for Growth and Competitiveness in China: Experience with Special Economic Zones and Industrial Clusters; Zeng, D.Z., Ed.; International Bank for Reconstruction and Development/World Bank: Washington, DC, USA, 2010; pp. 151-179.

24. Guo, D.; Jang, K.; Xu, C.; Yang, X. Clustering, growth and inequality in China. J. Econ. Geogr. 2020, 20, 1207-1239. [CrossRef]

25. Kowalski, A.M. The perspectives on interregional cluster cooperation under BRI Frame. In Opportunities and Challenges. Sustainability of China-EU Relations in a Changing World; Shi, J., Heiduk, G., Eds.; China Social Sciences Press: Beijing, China, 2019 ; pp. 189-209.

26. McPhillips, M. Trouble in Paradise? Barriers to Open Innovation in Regional Clusters in the Era of the 4th Industrial Revolution. J. Open Innov. Technol. Mark. Complex. 2020, 6, 84. [CrossRef]

27. Capone, F.; Innocenti, N. Open innovation and network dynamics. An analysis of openness of co-patenting collaborations in Florence, Italy. Compet. Rev. 2020, 30, 4. [CrossRef]

28. Klevorick, A.K.; Levin, R.C.; Nelson, R.R.; Winter, S.G. On the sources and significance of inter-industry differences in technological opportunities. Res. Policy 1995, 24, 185-205. [CrossRef]

29. Bercovitz, J.E.L.; Feldman, M.P. Fishing upstream: Firm innovation strategy and university research alliances. Res. Policy 2007, 36, 930-948. [CrossRef]

30. Colombo, M.G.; Piva, E. Knowledge misappropriation risks and contractual complexity in entrepreneurial ventures' non-equity alliances. Small Bus. Econ. 2019, 53, 107-127. [CrossRef]

31. Liu, X.; Xia, T.; Lu, J.; Lin, D. Under what institutional conditions does overseas business knowledge contribute to firm performance? Int. Bus. Rev. 2019, 28, 588-602. [CrossRef]

32. Sultana, N.; Turkina, E. Foreign direct investment, technological advancement, and absorptive capacity: A network analysis. Int. Bus. Rev. 2020, 29, 101668. [CrossRef]

33. Cooke, P. Regional knowledge capabilities and open innovation: Regional innovation systems and clusters in the asymmetric knowledge economy. Clust. Netw. Innov. 2005, 22, 80-109.

34. Asheim, B.T.; Isaksen, A.; Martin, R.; Trippl, M. The role of clusters and public policy in new regional economic path development. In The Life Cycle of Clusters: A Policy Perspective; Fornahl, D., Hassink, R., Eds.; Edward Elgar Publishing: Cheltenham, UK, 2017; pp. 13-34.

35. Sopoligová, M.; Pavelková, D. Cluster policy in Europe and Asia: A comparison using selected cluster policy characteristics. J. Int. Stud. 2017, 10, 35-50. [CrossRef] [PubMed]

36. Dai, R.; Mookherjee, D.; Quan, Y.; Zhang, X. Industrial Clusters, Networks and Resilience to The Covid-19 Shock in China. Natl. Bur. Econ. Res. 2020. [CrossRef]

37. Porter, M.E.; Kramer, M.R. Creating Shared Value. In Harvard Business Review; Springer: Dordrecht, The Netherlands, 2011. 